\title{
The effect of Omega-3 fatty acid on Adiponectin and potential implication for obesity management
}

\author{
Rawaa J A Matloob*, Shamil H Othman** \\ * AL-Salam Teaching Hospital, Nineveh Health Directorate, Ministry of Health, Iraq, **Department of Pharmacology, College of \\ Medicine, University of Mosul, Mosul, Iraq. \\ Correspondence: Shamil Hashim Othman. Shamilalnuaimi@yahoo.com.
}

(Ann Coll Med Mosul 2018; 40 (2): 34-40).

Received: $10^{\text {th }}$ Jun. 2018; Accepted: $9^{\text {th }}$ Sep. 2018.

\section{ABSTRACT}

Objective: To evaluate the effect of 2 months use of omega- 3 fatty acids on adiponectin and other parameters contribute to weight control in healthy obese volunteers like body mass index (BMI), waist and hip circumferences and to compare the concentrations of adiponectin between interventional groups and control groups.

Design: Open-labeled randomized trial.

Method: This study included seventy- eight volunteers, aged 20-55 years with different gender and BMI. The patients were divided into 2 groups, namely the omega- 3 alone group which consisted of 25 obese subjects and the second one consisted of 26 obese subjects which represented the omega- 3 and diet group. The subjects groups were followed for 2 months during which the above parameters were measured before starting therapy and at the end of the follow-up period using commercially available kits. The patient groups were compared with a control group consisted of 67 apparently healthy subjects. The determination of adiponectin concentration in human serum was done using ELISA technique

Results: Significant differences were found regarding adiponecin $(p=0.001)$ in the interventional groups in comparison with control group. The studied parameters were compared in the omega- 3 groups and showed non-significant differences between the two studied groups concerning serum adiponectin $(p=0.065)$. By comparing the studied parameters in the omega- 3 alone group after 2 months of treatment, a significant differences were found in serum adiponectin $(p=0.012)$. The use of omega- 3 with diet for 2 months of treatment resulted in a significant increase in serum adiponectin $(p=0.000)$. The percentage improvement in the studied parameters in the first group after 2 months of treatment showed highly significant increase in serum adiponectin $(114.53 \%)$ with $p$-value $(0.000)$. While in the second group, highly significant increase in serum adiponectin (214.10\%) with p-value (0.000) were obtained.

Conclusion: The level of Adiponectin was significantly increased in interventional groups compared to control. The level of Adiponectin was very significantly increased in omega-3 with diet group compared with omega-3 alone group which reflected on the improvement in anthropometric parameters such as weight and BMI.

Keywords: Adiponectin, obesity, omega-3 fatty acids.

$$
\begin{aligned}
& \text { تأثير اويغا-ب على اديبونكتين والدور المحتمل في علاج السمنة }
\end{aligned}
$$

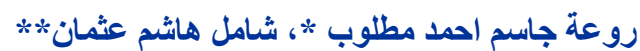

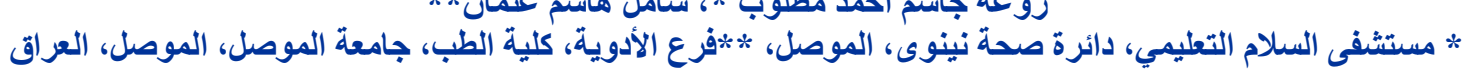

$$
\begin{aligned}
& \text { أهداف الدراسة: تهدف الدر اسة الحالية الى تقييم تأثير أستخدام شهرين من الأحماض الأمينية أميغا_ب على الأدييونكتين و المعايير }
\end{aligned}
$$

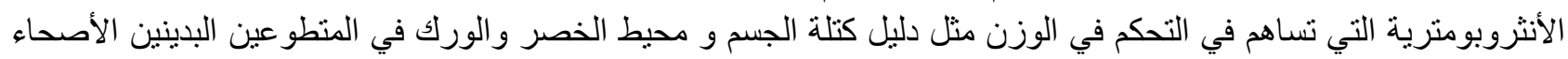

$$
\begin{aligned}
& \text { ومقارنة تركيز أديبونكتين بين المجمو عات التداخلية مع مجمو عة الضبط دليط. }
\end{aligned}
$$




$$
\text { تصميم الاراسة: تجربة عشوائية (مفتوحة_المجال). }
$$

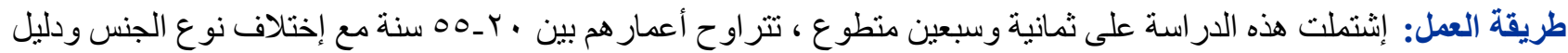

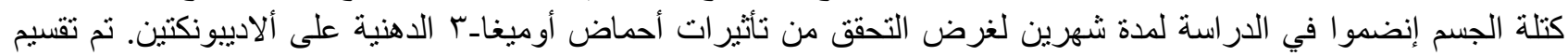

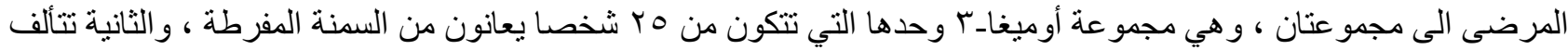

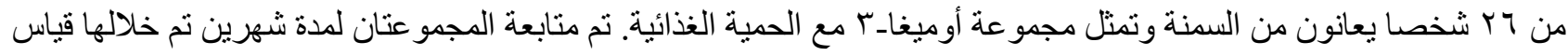

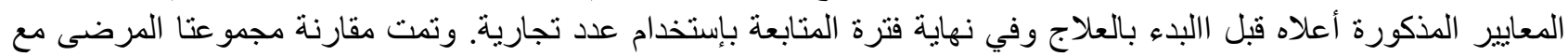

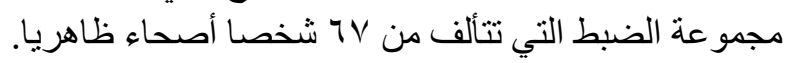

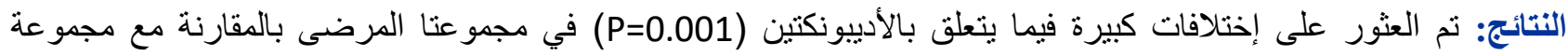

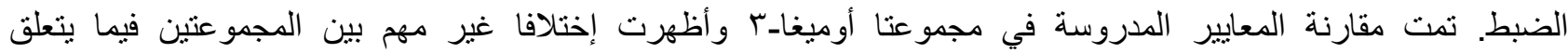

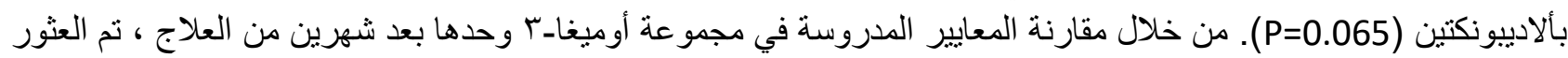

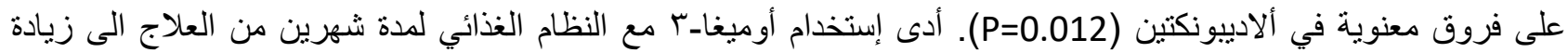

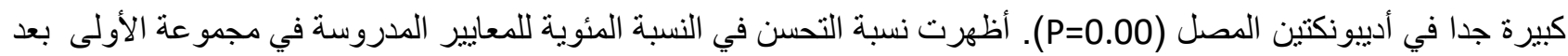
شهرين من العلاج زيادة معنوية كبيرة في ألادييونكتين (114,53\%) بينما في المجموعة الثانية ، تم الحصول على زيادة كبيرة للغاية في ألادييونكتين (214,10\%).

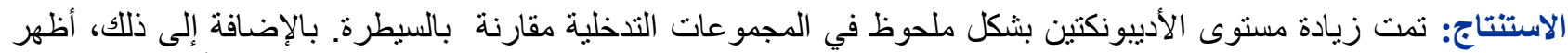

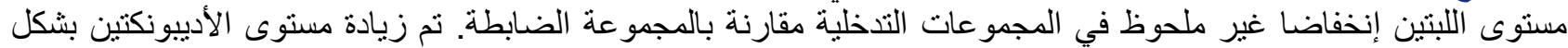

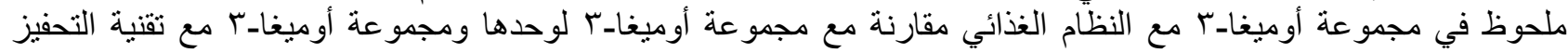
الثحمي (ترددات الر اديو) المساعدة.

كلمات الدلالة: أدييونكتين، السمنة، الأحماض الأمينية أوميغا-ب.

\section{INTRODUCTION}

O verweight and obesity (defined as excess body weight for height) have genetic, behavioral, socioeconomic, and environmental origins ${ }^{1}$. Obesity is a multifactorial and largely preventable disease affecting over a third of the world's population today ${ }^{2,3}$. Body Mass Index (BMI) is a simple index of weight-for-height that is commonly used by World Health Organization (WHO) to classify underweight, overweight and obesity in adults, defined as the weight in kilograms divided by the square of the height in meters $\left(\mathrm{kg} / \mathrm{m}^{2}\right)^{4}$. The measurements of body fat used in clinical practice are BMI, Waist circumference, and Waist/Hip ratio ${ }^{5,6}$.

Adipose tissue can regulate energy homeostasis through action of the secreted adipokines and one of these include the hormone Adiponectin. Altered levels of Adiponectin is correlated with obesity $^{7}$. Adiponectin is a 224 -amino acid protein secreted mainly by the adipose tissue. Serum levels of Adiponectin decrease with obesity and positively associated with insulin sensitivity ${ }^{8}$.
The Proposed mechanism by which omega-3 fatty acid may work to improve body composition and counteract obesity- related metabolic changes include: modulating lipid metabolism; regulating adipokines, such as Adiponectin; alleviating adipose tissue inflammation; promoting adipogenesis; and altering epigenetic mechanisms 9,10. Omega-3 fatty acids activate PPAR-y in adipose tissue, increasing the expression, secretion and plasma levels of the antiinflammatory hormone adiponectin and decrease plasma triglyceride concentration ${ }^{11,12}$. The present study aims to evaluate the effect of 2 month use of omega-3 fatty acids on adiponectin and other parameters contribute on weight control in healthy obese volunteers, to compare the concentrations of adiponectin and other parameters between interventional groups and control group.

\section{SUBJECTS AND METHODS}

The subjects included in this study were selected over the six-month period. To achieve the aim of the present study, an open-labeled randomized 
trial, was adopted. Seventy eight patients whose ages mean $\pm S D$ were $34.13 \pm 8.06$ years with obesity diagnosed according to WHO criteria were completed the two months follow-up period. The volunteers were divided into two groups. The first group consisted of twenty-five volunteers started to receive omega 3 soft gel capsule $1000 \mathrm{mg}$ once daily. The second group consisted of twenty-six volunteers also started to receive omega 3 soft gel capsule once daily with same dose in addition to receive low calorie diets(800-1800 Kcal divided into three meals) ${ }^{13}$. The study was approved by the ethical committee of Nineveh Health Directorate. Sixty-seven apparently healthy volunteers, matched for age and gender with grouped volunteers, were considered as a control group. Weight, height, waist circumference and hip circumference were measured for each participant in the study. BMI was calculated by following equation:

$$
\mathrm{BMI}=\text { weight }(\mathrm{kg}) / \text { height }\left(\mathrm{m}^{2}\right)^{4}
$$

Waist and hip circumference were measured by a non-stretchable flexible tape (Butterfly made in china).

The waist/hip ratio was measured from waist and hip circumference.

About $5 \mathrm{ml}$ of venous blood was withdrawn prior to start taking the drug and after two months of the drug use. The serum was separated by centrifugation at $3000 \mathrm{rpm}$ for 10 minutes and kept frozen at $-20{ }^{\circ} \mathrm{C}$ to be analyzed later on. Sample from the control volunteers were collected once and processed in the same way. The determination of adiponectin concentration in human serum was done using ELISA technique ${ }^{14}$, using Human Adiponectin Platinum ELISA BMS2032/2, Europe.

\section{Statistical analysis}

The descriptive statistics include mean \pm Standard Deviation (SD) for quantitative variables and frequency and percentage for qualitative data. Independent t-test of two means (unpaired) was used for comparison between each two quantitative parameters (intervention vs. control).

Dependent t-test of two means (paired) was applied for the differences in intervention groups (before _ after). For comparison between more than two groups, one-way ANOVA-test with Tukey's Pair wise comparisons was used.
Percentage improvement rate was calculated in intervention groups as follow:

$\%$ improvement rate $=\frac{\text { before intervention-after intervention }}{\text { before intervention }} \times 100$.

P-values $\leq 0.05$ were considered statistically significant throughout data analysis ${ }^{15}$.

\section{RESULTS}

The characteristics of the patients and controls were presented in Table (1 and $\mathbf{2}$ ) respectively .

Table (3) showed that the weight and BMI were very significantly different $(p<0.0001)$ in the interventional groups than in the control group and the waist and hip circumferences were significantly different $(p=0.046$ and $p=0.026)$ respectively with non-significant changes in height and waist/hip ratio in interventional groups before starting therapy as compared with the control group.

Table (4) demonstrated the comparison in personal and anthropometric parameters between the three Omega-3 groups at base line and showed a significant differences regarding age $(p=0.039)$ and height $(p=0.037)$ among the three omega-3 groups with non-significant differences regarding other parameters within the same groups.

Table 1. Personal characteristics of intervention groups $(\mathrm{n}=78)$.

\begin{tabular}{lcccc}
\hline Characteristics & Mean & SD & Minimum & Maximum \\
\hline Age (years) & 34.13 & 8.06 & 20.00 & 53.00 \\
\hline BMI (kg/m2) & 32.49 & 5.72 & 30.20 & 43.10 \\
\hline Gender & No. & $\%$ & & \\
$\quad$ Male & 29 & 37.18 & & \\
$\quad$ Female & 49 & 62.82 & & \\
Marital status:* & & & \\
$\quad$ Single & 22 & 28.21 & & \\
$\quad$ Married & 56 & 71.79 & & \\
\hline * No widow nor divorced person in the study sampled \\
population.
\end{tabular}

Table 2. Personal characteristics of control group $(\mathrm{n}=67)$.

\begin{tabular}{lccll}
\hline Characteristics & Mean & SD & Minimum & Maximum \\
\hline Age $($ years) & 36.60 & 9.49 & 21.00 & 55.00 \\
\hline BMI(kg/m²) & 27.44 & 1.39 & 24.80 & 29.70 \\
\hline Gender & No. & $\%$ & & \\
$\quad$ Male & 18 & 26.87 & & \\
$\quad$ Female & 49 & 73.13 & & \\
$\begin{array}{l}\text { Marital status:* } \\
\quad \text { Single }\end{array}$ & 9 & 13.43 & & \\
$\quad$ Married & 58 & 86.57 & & \\
\hline $\begin{array}{l}\text { * No widow nor } \\
\text { population. }\end{array}$ & & & & \\
\hline
\end{tabular}


Table 3. Comparison of anthropometric parameters between the interventional groups and control group at the beginning of the study.

\begin{tabular}{|c|c|c|c|}
\hline Parameters & $\begin{array}{c}\text { Interventional } \\
\text { groups }[\mathrm{n}=78] \\
\text { Mean } \pm \mathrm{SD}\end{array}$ & $\begin{array}{c}\text { Control group } \\
{[n=67]} \\
\text { Mean } \pm \text { SD }\end{array}$ & $\begin{array}{c}\text { P- } \\
\text { value* }\end{array}$ \\
\hline Height (cm) & $163.91 \pm 9.27$ & $162.07 \pm 9.12$ & 0.233 \\
\hline Weight (kg) & $87.7 \pm 16.8$ & $72.52 \pm 8.93$ & 0.000 \\
\hline BMI $\left(\mathrm{kg} / \mathrm{m}^{2}\right)$ & $32.49 \pm 5.72$ & $27.44 \pm 1.39$ & 0.000 \\
\hline $\begin{array}{l}\text { Waist } \\
\text { circumference } \\
(\mathrm{cm})\end{array}$ & $108.6 \pm 14.0$ & $104.0 \pm 13.6$ & 0.046 \\
\hline $\begin{array}{l}\text { Hip } \\
\text { circumference } \\
\text { (cm) }\end{array}$ & $120.6 \pm 12.9$ & $116.0 \pm 11.6$ & 0.026 \\
\hline $\begin{array}{l}\text { Waist/ Hip } \\
\text { ratio }\end{array}$ & $0.90 \pm 0.08$ & $0.89 \pm 0.09$ & 0.794 \\
\hline
\end{tabular}

Table 4. Comparison of personal and anthropometric parameters between the two Omega- 3 groups at base line.

\begin{tabular}{|c|c|c|c|}
\hline \multirow[b]{2}{*}{ Parameters } & \multicolumn{2}{|c|}{ Omega-3 groups } & \multirow[b]{2}{*}{$\begin{array}{c}\text { P- } \\
\text { value* }^{*}\end{array}$} \\
\hline & $\begin{array}{c}\text { Omega-3 } \\
\text { alone } \\
{[n=25]} \\
\text { Mean } \pm \text { SD }\end{array}$ & $\begin{array}{c}\text { Omega-3 } \\
\text { with diet } \\
{[n=26]} \\
\text { Mean } \pm \text { SD }\end{array}$ & \\
\hline Age (years) & $37.44 \pm 7.94^{\mathrm{A}}$ & $32.12 \pm 7.96^{\mathrm{B}}$ & 0.039 \\
\hline Height (cm) & $166.76 \pm 9.67^{A}$ & $164.81 \pm 9.39^{\mathrm{AB}}$ & 0.037 \\
\hline Weight (kg) & $86.64 \pm 14.70^{A}$ & $89.00 \pm 18.64^{A}$ & 0.878 \\
\hline BMI $\left(\mathrm{kg} / \mathrm{m}^{2}\right)$ & $30.96 \pm 4.36^{A}$ & $32.59 \pm 5.21^{A}$ & 0.201 \\
\hline $\begin{array}{l}\text { Waist } \\
\text { circumference } \\
\text { (cm) }\end{array}$ & $104.1 \pm 14.23^{A}$ & $104.6 \pm 14.68^{A}$ & 0.947 \\
\hline $\begin{array}{l}\text { Hip } \\
\text { circumference } \\
\text { (cm) }\end{array}$ & $111.32 \pm 8.69^{A}$ & $118.46 \pm 10.83^{A}$ & 0.051 \\
\hline $\begin{array}{l}\text { Waist/Hip } \\
\text { ratio }\end{array}$ & $0.93 \pm 0.10^{A}$ & $0.88 \pm 0.09^{A}$ & 0.068 \\
\hline
\end{tabular}

Table (5) demonstrated the comparison between the studied parameters in the omega-3 alone group and the control group after 2 months of treatment and showed very significant differences $(p=0.000)$ regarding BMI, hip circumference, with significant differences concerning waist circumference $(p=0.002)$, and serum adiponectin $(p=0.012)$ and non-significant differences regarding waist/hip ratio $(\mathrm{p}=0.781)$.

Table (6) demonstrated the changes in the studied parameters in omega-3 with diet group after 2 months of treatment and showed very significant decreases $(p=0.000)$ in BMI, waist circumference, hip circumference, $\mathrm{W} / \mathrm{H}$ ratio, with very significant increase in serum adiponectin $(\mathrm{p}=0.000)$.

Table (7) demonstrated the comparison between the studied parameters in the omega- 3 with diet group and the control group after 2 months of treatment and showed very significant differences $(p=0.000)$ regarding BMI, waist circumference, with significant differences concerning hip circumference $(p=0.004)$, serum adiponectin $(p=0.001)$ and waist/hip ratio $(p=0.001)$.

Table (8) demonstrated the percentage improvement in the studied parameters in the omega-3 alone group after 2 months of treatment and showed highly significant decreases in waist circumference $(5.86 \%)$, hip circumference $(3.11 \%)$, with significant decrease in BMI (1.62\%) and waist/hip ratio $(2.15 \%)$. The table also showed highly significant increase in serum adiponectin (114.53\%).

Table 5. Comparison of anthropometric and hormonal parameters between "Omega-3 alone" group and control group after 2 months.

\begin{tabular}{|c|c|c|c|}
\hline Parameters & $\begin{array}{c}\text { Omega-3 } \\
\text { alone } \\
{[n=25]} \\
\text { Mean } \pm \text { SD }\end{array}$ & $\begin{array}{c}\text { Control } \\
{[n=67]} \\
\text { Mean } \pm S D\end{array}$ & $\begin{array}{c}\text { P- } \\
\text { value* }\end{array}$ \\
\hline BMI $\left(\mathrm{kg} / \mathrm{m}^{2}\right)$ & $30.46 \pm 4.82$ & 27.4 & 0.000 \\
\hline $\begin{array}{l}\text { Waist } \\
\text { circumference } \\
\text { (cm) }\end{array}$ & $98.0 \pm 13.83$ & $108.6 \pm 14.0$ & 0.002 \\
\hline $\begin{array}{l}\text { Hip } \\
\text { circumference } \\
\text { (cm) }\end{array}$ & $107.86 \pm 8.89$ & $120.6 \pm 12.9$ & 0.000 \\
\hline $\mathrm{W} / \mathrm{H}$ ratio & $0.91 \pm 0.10$ & $0.90 \pm 0.08$ & 0.781 \\
\hline $\begin{array}{l}\text { Adiponectin } \\
\text { (ng/ml) }\end{array}$ & $6.35 \pm 2.96$ & $4.46 \pm 3.19$ & 0.012 \\
\hline
\end{tabular}

Table 6. Changes of anthropometric and hormonal parameters in participants receiving Omega-3 with diet regimen.

\begin{tabular}{lccc}
\hline Parameters & $\begin{array}{c}\text { Base line } \\
\text { Mean } \pm \text { SD }\end{array}$ & $\begin{array}{c}\text { After } 2 \\
\text { months } \\
\text { Mean } \pm \text { SD }\end{array}$ & $\begin{array}{c}\text { P- } \\
\text { value* }\end{array}$ \\
\hline $\begin{array}{l}\text { BMI }\left(\mathrm{kg} / \mathrm{m}^{2}\right) \\
\text { Waist }\end{array}$ & $32.30 \pm 5.10$ & $31.04 \pm 4.76$ & 0.000 \\
$\begin{array}{l}\text { circumference } \\
(\mathbf{c m})\end{array}$ & $104.6 \pm 14.68$ & $94.4 \pm 14.83$ & 0.000 \\
$\begin{array}{l}\text { Hip } \\
\text { circumference } \\
(\mathbf{c m})\end{array}$ & $118.46 \pm 10.83$ & $113.23 \pm 10.05$ & 0.000 \\
$\begin{array}{l}\text { W/H ratio } \\
\begin{array}{l}\text { Adiponectin } \\
\text { (ng/ml) }\end{array}\end{array}$ & $0.88 \pm 0.10$ & $0.83 \pm 0.10$ & 0.000 \\
\hline${ }^{*}$ Paired T-test of two means was used. & $7.13 \pm 3.59$ & 0.000 \\
\hline
\end{tabular}


Table (9) illustrated the percentage improvement in the studied parameters in the omega- 3 with diet group after 8 weeks of treatment and showed highly significant decreases in BMI (3.90\%), waist circumference $(9.75 \%)$, hip circumference $(4.42 \%)$, waist/hip ratio $(5.68 \%)$. The table also showed highly significant increase in serum adiponectin (214.10\%).
Table 7. Comparison of anthropometric and hormonal parameters between "Omega-3 with diet regimen" group and control group after 8 weeks.

\begin{tabular}{lccc}
\hline \multicolumn{1}{c}{ Parameters } & $\begin{array}{c}\text { Omega- } \\
\text { 3+diet } \\
{[\mathrm{n}=26]} \\
\text { Mean } \pm \text { SD }\end{array}$ & $\begin{array}{c}\text { Control } \\
{[\mathrm{n}=67]} \\
\text { Mean } \pm \text { SD }\end{array}$ & $\begin{array}{c}\text { P- } \\
\text { value* }^{*}\end{array}$ \\
\hline $\begin{array}{l}\text { BMI }\left(\mathrm{kg} / \mathrm{m}^{2}\right) \\
\text { Waist }\end{array}$ & $31.04 \pm 4.76$ & $27.44 \pm 1.39$ & 0.000 \\
$\begin{array}{l}\text { circumference } \\
(\mathrm{cm})\end{array}$ & $94.4 \pm 14.83$ & $108.6 \pm 14.0$ & 0.000 \\
$\begin{array}{l}\text { Hip } \\
\text { circumference } \\
(\mathrm{cm})\end{array}$ & $113.23 \pm 10.05$ & $120.6 \pm 12.9$ & 0.004 \\
$\begin{array}{l}\text { W/H ratio } \\
\begin{array}{l}\text { Adiponectin } \\
\text { (ng/ml) }\end{array}\end{array}$ & $0.83 \pm 0.10$ & $0.90 \pm 0.08$ & 0.001 \\
\hline * Independent T-test of two means was used. & \\
\hline
\end{tabular}

Table 8. Percentage improvement rates in anthropometric and hormonal parameters of Omega-3 alone group ( $\mathrm{n}=25)$.

\begin{tabular}{|c|c|c|c|c|c|}
\hline Parameters & $\begin{array}{l}\text { Beginning } \\
\text { Mean } \pm \text { SD }\end{array}$ & $\begin{array}{l}\text { After } 2 \text { months } \\
\text { Mean } \pm \text { SD }\end{array}$ & $\begin{array}{l}\text { Before } \\
\text { - after }\end{array}$ & $\begin{array}{l}\text { \% improvement } \\
\text { rate }\end{array}$ & P-value \\
\hline BMI $\left(\mathrm{kg} / \mathrm{m}^{2}\right)$ & $30.96 \pm 4.36$ & $30.46 \pm 4.82$ & 0.50 & 1.62 & 0.010 \\
\hline $\begin{array}{l}\text { Waist } \\
\text { circumference (cm) }\end{array}$ & $104.1 \pm 14.23$ & $98.0 \pm 13.83$ & 6.1 & 5.86 & 0.000 \\
\hline $\begin{array}{l}\text { Hip circumference } \\
(\mathrm{cm})\end{array}$ & $111.32 \pm 8.69$ & $107.86 \pm 8.89$ & 3.46 & 3.11 & 0.000 \\
\hline W/H ratio & $0.93 \pm 0.10$ & $0.91 \pm 0.10$ & 0.02 & 2.15 & 0.008 \\
\hline Adiponectin (ng/ml) & $2.96 \pm 2.25$ & $6.35 \pm 2.96$ & - 3.39 & 114.53 & 0.000 \\
\hline
\end{tabular}

Table 9. Percentage Improvement rates in anthropometric and hormonal parameters of Omega-3 with diet regimen group $(n=26)$.

\begin{tabular}{lccccc}
\hline \multicolumn{1}{c}{ Parameters } & $\begin{array}{c}\text { Beginning } \\
\text { Mean } \pm \text { SD }\end{array}$ & $\begin{array}{c}\text { After } 8 \text { weeks } \\
\text { Mean } \pm \text { SD }\end{array}$ & $\begin{array}{c}\text { Before } \\
\text { - after }\end{array}$ & $\begin{array}{c}\text { \% improvement } \\
\text { rate }\end{array}$ & P-value \\
\hline BMI $\left(\mathrm{kg} / \mathrm{m}^{2}\right)$ & $32.30 \pm 5.10$ & $31.04 \pm 4.76$ & 1.26 & 3.90 & 0.000 \\
Waist circumference & $104.6 \pm 14.68$ & $94.4 \pm 14.83$ & 10.20 & 9.75 & 0.000 \\
$(\mathrm{~cm})$ & $118.46 \pm 10.83$ & $113.23 \pm 10.05$ & 5.23 & 4.42 & 0.000 \\
Hip circumference $(\mathrm{cm})$ & $0.88 \pm 0.10$ & $0.83 \pm 0.10$ & 0.05 & 5.68 & 0.000 \\
W/H ratio & $2.27 \pm 1.96$ & $7.13 \pm 3.59$ & -4.86 & 214.10 & 0.000 \\
\hline Adiponectin $(\mathrm{ng} / \mathrm{ml})$ & & &
\end{tabular}

\section{DISCUSSION}

In the current study, serum level of Adiponectin was found significantly lower in obese individuals than the in control subjects as shown in Table (5).

Alteration in Adiponectin levels have been shown to affect lipid and glucose metabolism that further increase the synthesis of lipid, free fatty acid and inflammatory cytokines ${ }^{16}$. It has been reported that decreased circulatory levels of adiponectin in obesity (despite being produced in adipose tissue) are inversely correlated with body fat percentage in adults $^{17}$. Our study was in agreement with the results of Van Zyl et al., (2017) ${ }^{18}$ and Fruhbeck et al, $(2018)^{19}$ whom found that the serum level of
Adiponectin was significantly lower in obese patients.

Omega-3 fatty acids were shown to increase plasma levels of Adiponectin in rodents and human subjects. This effect of omega- 3 fatty acids on plasma levels of adipokines may be in part a result of activation of PPAR- $y^{20}$. Baynes et al, (2018) depend on using prospective and retrospective studies, cohert studies, systematic reviews, experimental studies and case - control studies that were done previously and was reported that after treatment with omega-3 fatty acids, an increase in adiponectin level was found. ${ }^{21,22}$ 
In the current study, the use of Omega-3 over two months period in the two interventional groups resulted in significant increase in Adiponectin in comparison with control group. There are no significant difference in this parameter in the two interventional groups. This is not surprising, as clinical trials have reported same results in metabolic and hormonal parameters ${ }^{7}$.

Regarding to anthropometric measurements (weight, BMI, waist circumference, hip circumference and waist/hip ratio), the current study found that these measurements were significantly higher in comparison with control as shown in Table (3). The results of Lam et al, ( 2015) was in agreement with current study who found that higher anthropometric measurements in obese subjects and consider these measurements as predictors of obesity ${ }^{23}$.

The results of the current study found that two month use of omega- 3 fatty acids was resulted in significant decreases in BMI, waist circumference, hip circumference and waist/hip ratio in both sexes in the interventional groups in comparison with control, except in group 1 where non- significant differences were found regarding waist/hip ratio as shown in Tables (6 and 7 ) respectively.

In agreement with the results of the current study were that of Arias-Rico et al .,(2018) ${ }^{24}$ who found that omega-3 fatty acids improved anthropometric measurements (weight, BMI, waist circumference, hip circumference and waist/hip ratio) in the study groups in comparison with control. The study of Gonzalelez-Acevedo et al, (2013) ${ }^{25}$ and that of Howe and Buckley ,(2014) ${ }^{26}$ lies in agreement with our results who found that omega- 3 fatty acids significantly reduced weight, BMI, and total fat mass and inversely related to waist and hip circumference. In contrast to the results of the current study were that of Root et al, (2013) ${ }^{27}$ and Hastert et al, (2018) ${ }^{28}$ who reported that omega-3 did not affect BMI and waist circumference over 4 weeks period.

In the current study, the percentage Improvement rates in anthropometric and serum adiponectin were calculated in the interventional groups. All these parameters have nearly similar rates of improvement in the interventional groups after two month period. But the Adiponectin level showed very high rate of improvement $(214.1 \%)$ in omega-3 with diet group compared with
(114.53\%) in omega-3 alone group, which means that Adiponectin level did not only effected by omega-3 intake alone and the low calorie diet has an effect in this concern as shown in tables (8 and 9) respectively. Our results regarding Adiponectin were in agreement with Silva et al, $(2011)^{29}$ who reported that a low-calorie diet increased Adiponectin level and concluded that dietary management can be an effective therapeutic means of increasing Adiponectin levels in obese subjects.

De Luis et al, (2018) ${ }^{30}$ in their randomized clinical trial on 284 obese patients have another explanation for increasing Adiponectin level. They reported an association between adiponectin gene types and increasing circulatory Adiponectin level in two hypocaloric diet groups and concluded that the GG genotype of ADIPOQ gene variant (rs 1501299) is associated with an increase in Adiponectin levels in both hypocaloric diet groups. In conclusion, the level of Adiponectin was significantly increased in interventional groups compared to control group. In addition. The level of Adiponectin was very significantly increased in omega-3 with diet group compared with omega-3 alone group.

\section{REFERENCES}

1.Hruby A, Frank B. The Epidemiology of Obesity: A Big Picture. Pharmacoeconomics 2016; 33(7): 673-689.

2.Stevens GA, Singh GM, Lu Y, Danaei G, Lin JK, Finucane MM, et al .National, regional, and global trends in adult overweight and obesity prevalence. Popul Health Metr 2012; 10(1): 22.

3.Ng M, Fleming $\mathrm{T}$, Robinson $\mathrm{M}$, Thomson $\mathrm{B}$, Graetz $\mathrm{N}$, Margono $\mathrm{C}$, et al. Global, regional, and national prevalence of overweight and obesity in children and adults during 1980-2013: a systemic analysis for the Global Burden of Disease Study 2013. The Lancet 2013, 384(9945): 766-51.

4.World Health Organization, WHO. Obesity and overweight. 2016 [cited 2017 Febrero], http://www. who.int/mediacentre/factsheet/fs311/en/.

5.Garvey WT, Mechanick JI, Brett EM , Garber AJ, Hurley DL, Jastreboff AM et al.American association of clinical endocrinologists and American college of endocrinology clinical practice guidelines for comprehensive medical care of patients with obesity executive summary. Endocrine practice 2016; 22(3): 113.

6.Hamdy O .Obesity: Practice Essentials, Background, pathophyiology workshop Summary. Medscape Medical News 2018 Mar; 20.

7.Gray B, Steyn F, Davies PS, Vitetta L .Omega-3 fatty acids: a review of the effects on adiponectin and leptin and potential implications for obesity management. 
European Journal of Clinical Nutrition 2013; 67(12): 1234-42.

8.Achari $A E$ and JainSK. Adiponectin, a Therapeutic Target for Obesity, Diabetes, and Endothelial Dysfunction .International Journal of Molecular Sciences 2017; 18(6): 1321.

9.Kuda O, Rossmeisl M, Kopecky J . Omega-3 fatty acids and adipose tissue biology. Mol Aspects Med 2018 ; 98(17): 30162-0.

10.Albracht-Schulte K, Kalupahana NS, Ramalingam L, Wang S, Rahman S, Robert-McComb J et al. Omega-3 fatty acids in obesity and metabolic syndrome: A mechanistic update. The Journal of Nutritional Biochemistry 2018; 58: 1-16.

11.Kordoni ME, Panagiotakos D . Can dietary omega3fatty acid supplementation reduce inflammation in obese pregnant women: A Discussion of a Randomized Double-Blind Controlled Clinical Trial. Hellenic Atherosclerosis Society 2017; 8(4): 121-128.

12.Bersch-Ferreira AC, Sampaio GR, Gehringer MO, Torres EAFDS, Ross-Fernandes MB, Da Silva JT et al. Association between plasma fatty acids and inflammatory markers in patients with and without insulin resistance and in secondary prevention of cardiovascular disease, a cross-sectional study. Nutrition Journal 2018;17(1):26.

13. Hamdy O, Khardori R. Obesity: Practice Essentials, Background, pathophysiology workshop summary. Medscape Med News 2018; Mar 20.

14. Hao $\mathrm{Y}$, Ma X, Luo $\mathrm{Y}, \mathrm{Hu} \mathrm{X}$, Pan X, Xiao $\mathrm{Y}$ et al .Associations of Serum Adipocyte Fatty Acid Binding Protein With Body Composition and Fat Distribution in Nondiabetic Chinese Women. The Journal of Clinical Endocrinology \& Metabolism 2015; 100(5): 2055-2062.

15.Chap T. Le. Probability and probability models .In:Chap T.Le editor.Introductory Biostatistics.1st ed. New Jersy:John Wiley and Sons Publications; 2003.P:108-140

16.Ghadge AA, Khaire AA, Kuvalekar AA .Adiponectin: A Potential therapeutic target for metabolic syndrome. Cytokine Growth Factor Rev 2018; 39: 151-158.

17.Diwan AG, Kuvalekar AA, Dharamsi S, Vora AM, Nikam VA, Ghadge AA .Correlation of serum Adiponectin and leptin levels in obesity and Type 2 diabetes mellitus. Indian Journal of Endocrinology and Metabolism 2018; 22(1): 93-99.

18.Van Zyl S, Merwe LJVD, Van Rooyen FC, Joubert G, Walsh CM .The relationship between obesity, leptin, Adiponectin and the components of metabolic syndrome in urban African woman, Free State, South Africa, South African Journal of Clinical Nutrition 2017; 30(3): 68-73.

19.Frühbeck $G$, Catalăn $V$, Rodrîguez $A$, GơmezAmbrosi J .Adiponectin-leptin ratio: A promising index to estimate adipose tissue dysfunction. Relation with obesity-associated cardiometabolic risk. Adipocyte;7(1): 57-62.
20.Chajès V, Torres-Mejîa $G$, Biessy $C$, Ortega-Olvera C, Angeles-Llerenas A, Ferrari P et al ., (2012). W-3 and $\omega-6$ polyunsaturated fatty acid intakes and the risk of breast cancer in Mexican Women: impact of obesity status. Cancer Epidemiol Biomarkers Prev 2018; 21(2): 319-26.

21.Baynes HW, Mideksa S, Ambachew $S$. The role of polyunsaturated fatty acids ( $n-3$ PUFAS) on the pancreatic $\beta$-cells and insulin action/ Abstract PubMed. J Adipocyte2018:1-7.

22. Rafey MF, Fang CEH, Loana L, Griffin H, Hynes M, O'brien $\mathrm{T}$ et al. Influence of sleev gastrectomy on leptin to Adiponectin ratio in severely obese adults: A prospective cohert study. Endocrine Abstracts 2018; 56 : 605.

23.Lam BC, Koh GC, Chen C, Wong MT, Fallows SJ . Comparison of Body Mass Index (BMI), Body Adiposity Index(BAI), Waist Circumference (WC), Waist-To-Hip Ratio (WHR) and Waist-To-Hight Ratio(WHtR) as predictors of cardiovascular disease risk factors in an adult population in Singapore. PLoS One 2015; 10(4): e0122985.

24.Arias-Rico J, Cerón-Sandoval MI, Sandoval-Gallegos EM, Ramírez-Moreno E, Fernández-Cortés TL, JaimezOrdaz $\mathrm{J}$ et al. Evaluation of Consumption of Poulty Products Enriched with omega-3 Fatty Acids in Anthropometric, Biochemical, and Cardiovascular Parameters. Journal of Food Quality( Cairo) 2018;2018(18): 8.

25.González-Acevedo O, Hernández-Sierra JF, SalazarMartínez A, Mandeville PB, Valadez-Castillo FJ, De La Cruz-Mendoza $\mathrm{E}$ et al .[Effect of Omega3 fatty acids on body female obese composition] Randomized controlled trial. Arch Latinoam Nutr 2013; 63(3): 224-31.

26. Howe P, Buckley J .Metabolic Health Benefits of Long-Chain Omega-3 Polyunsaturated Fatty Acids. Military Medicine 2014; 179(11): 138.

27.Root M, Collier SR, Zwetsloot KA, West KL, McGinn MC .A randomized trial of fish oil omega-3 fatty acids on arterial health, inflammation, and metabolic syndrome in a young healthy population. Nutrition Journal 2013; 12 : 40.

28. Hastert TA, Otto MDO, Lê-Scherban F, Steffen BT, Steffen LM, Tsai MY et al.Association of plasma phospholipid polyunsaturated and trans fatty acids with body mass index: results from the Multi-Ethnic Study of Atherosclerosis. International Journal of Obesity 2018; 42(3): 433.

29.Silva FM, Almeida JCD, Feoli AM .Effect of diet on Adiponectin levels in blood. Nutrition reviews 2011; 69(10): 599-612.

30.De Luis DA, Izaola O, Primo D, Aller R, Ortola A, Gómez E, Lopez JJ .The association of SNP276G>T at Adiponectin gene with insulin resistance and circulating Adiponectin in response to two different hypocaloric diets. Diabetes research and clinical practice 2018; 137 : 93-99. 